\title{
Toward a Relational Economic Geography
}

\author{
Harald Bathelt \& Johannes Glückler
}

\author{
Version Post-print/accepted manuscript \\ Citation Bathelt, H., \& Glückler, J. (2003). Toward a relational economic \\ (published version) geography. Journal of Economic Geography, 3(2), 117-144.

\section{Copyright / License}

Publisher's Statement This is a pre-copyedited, author-produced PDF of an article accepted for publication in Journal of Economic Geography following peer review. The version of record [Bathelt, H., \& Glückler, J. (2003). Toward a relational economic geography. Journal of Economic Geography, 3(2), 117144.] is available online at: http://joeg.oxfordjournals.org/content/3/2/117 [doi: $10.1093 / \mathrm{jeg} / 3.2 .117]$.

Always cite the published version, so the author(s) will receive recognition through services that track citation counts, e.g. Scopus. If you need to cite the page number of the TSpace version (original manuscript or accepted manuscript) because you cannot access the published version, then cite the TSpace version in addition to the published version using the permanent URI (handle) found on the record page. 


\title{
Towards Relational Economic Geography
}

\author{
Harald Bathelt \\ Faculty of Geography, Philipps-University of Marburg, \\ Deutschhausstraße 10, D-35037 Marburg, F.R.G., \\ E-mail: bathelt@mailer.uni-marburg.de \\ and \\ Johannes Glückler \\ Institute of Economic and Social Geography, \\ Johann Wolfgang Goethe-University of Frankfurt/Main, \\ Postfach 111932, Dantestraße 9, D-60054 Frankfurt/Main, F.R.G., \\ E-mail: glueckler@em.uni-frankfurt.de
}

Paper Submitted to Journal of Economic Geography 


\title{
Towards Relational Economic Geography
}

\begin{abstract}
In this paper, we argue that a paradigmatic shift is presently occurring in economic geography. Based on the particular German tradition in geography, we view this shift as a second transition in economic geography following the first transition in the late 1960s and early 1970s from regional description and synthesis (i.e. Länderkunde) to regional science (or spatial analysis). Our argument starts with a reconstruction of factor-centered thinking in regional science and systematically unravels limits of this approach. It is shown that this research fails to provide a deeper understanding of localized economic and social processes.
\end{abstract} As a science of the spatial, this approach neglects the real actors in these processes. Economic agents are capable of creating their own regional environments to support their goals, based on previous experience. As a consequence, we argue for a need to reconceptualize economic geography based upon an integration of both economic and social theory. A relational view rests on three basic propositions. First, from a structural perspective economic actors are situated in contexts of social and institutional relations (and material structures). Second, from a dynamic perspective economic processes are path-dependent to the extent that future action is constrained by historical development. Third, economic processes are at the same time contingent in that the agents' strategies and actions are fundamentally open-ended and may deviate from existing development paths. Drawing on Storper's holy trinity, we define four ions as the basis for analysis in economic geography: organization, evolution, innovation and interaction. Therein, we employ a particular spatial perspective; that is, we view economic processes using a geographical lens. Economic organization and innovation are dependent upon localized institutions which constitute a common framework for economic interaction along territory-specific, yet contingent development paths. 
Keywords: Economic geography, regional science, relational economic geography, ions of economic geography. JEL Classifications : B41, B52, D83, L22, Z13. 


\section{Prelude: Multiple 'Turns' in Economic Geography?}

During the 1990s, a controversial debate has emerged in economic geography and other social sciences, such as economics and sociology, focusing on the question of what research program, key focus and methodology a novel economic geography should embody (Perrons, 2001). This was, partially, a reaction to the work of Krugman (1991), Fujita, Krugman and Venables (2001) and others who claimed to have developed a new economic geography. This self-proclaimed new economic geography offers an interesting economic perspective on the conventional problems of spatial distribution and equilibrium, based on an analysis of increasing returns, transportation costs and other traded interdependencies (Martin and Sunley, 1996; Bathelt, 2001). Yet it fails to develop a comprehensive research program as a basis for economic geography because "... the new economic geography ignores almost as much of the reality they study as old trade theory did" (Krugman, 2000, 50). ${ }^{1}$ In following Martin and Sunley's (1996) suggestion, this approach is better classified as geographical economics.

While this literature brings economic geography closer to the core ideas of neoclassical economics, Amin and Thrift (2000) have recently suggested another fundamentally different direction for economic geography, capitalizing on concepts and theories from other social sciences. Amin and Thrift $(2000,4)$ provocatively claim that economic geography is no longer able to 'fire the imagination' of researchers. Therefore, they ask for a critical reflection and renewal of this field's basic goals, concepts and methods. The reactions to their contribution have stimulated a debate, parts of which have been published in a special issue

\footnotetext{
${ }^{1}$ Berry (2002), one of the great thinkers in regional science, also criticizes the new economic geographers for their refusal to acknowledge previous academic contributions on similar topics. Further, their concept of space would be rather limited and partial.
} 
of Antipode in 2001. This debate has unfortunately been dominated by discipline-political arguments, opinions and claims. In essence, it focuses on the question of whether economic geography should be closely associated with economics or lean towards the social, political and cultural sciences. In particular, Thrift (2000) has identified a growing interest in the cultural dimension of economic relations, as well as in economic issues of cultural studies.

While Amin and Thrift (2000) propose a cultural turn away from neoclassical economics, their critics emphasize existing linkages with and the importance of economic theories as a foundation of economic geography (Martin and Sunley, 2001; Rodriguez-Pose, 2001). We agree with Martin and Sunley (2001) that this debate is partly based on false dualisms, such as economics vs. sociology and quantitative vs. qualitative methodology. In our view, this discussion is unclear because it mixes normative accounts of the discipline's policy implications with epistemological and methodological arguments. The debate is also somewhat misdirected for it tries to separate those economic and social aspects that are inseparable. The decisive question cannot be whether economic geography should be economized or culturalized. Rather, the economic and the social are fundamentally intertwined. They are dimensions of the same empirical reality which should be studied in a dialogue of perspectives rather than in mutual exclusion and reductionist prioritization (Stark, 2000). This is what we emphasize in our conceptualization of relational economic geography which we will develop in the following sections.

\section{Setting the Scene: Two Transitions in Economic Geography}

In this paper, we wish to contribute to the discussion aimed towards a reconceptualization of economic geography. We aim at a conceptual rather than a strategicpolitical renewal of the field. Based on the traditions in German geography, three broad paradigmatic approaches towards economic geography are distinguished which have developed sequentially over time. These are Länderkunde (i.e. science of regional description 
and synthesis), regional science (or spatial analysis) and relational economic geography. Although discussing this shift from the perspective of German geography, our intent is not to instigate a debate merely focusing on the state of contemporary economic geography in Germany. ${ }^{2}$ Apart from this, there is a much broader discussion about the conceptualization of economic geography, as has been indicated in the work of Amin and Thrift (2000), Scott (2000), Barnes (2001) and others. It is this debate to which we aim to contribute. Our intention is not to oversimplify the rich history of economic geography and state that the discipline has been characterized by three clear-cut research programs. Further, we do not intend to capture all of the different and sometimes contradictory approaches to economic geography, which have developed over time (for an overview, see, for instance, Schamp, 1983; Scott, 2000), into these broad categories to which we refer. We are, however, convinced that the paradigmatic approaches distinguished here have had and still have an important influence on the way how economic geographers have thought of their discipline and how economic geography has been structured over time.

${ }^{2}$ Even though our thinking has evolved within the context of German economic geography, we do not limit our argument to this particular context. We refer to the German context primarily to identify recent parallels between German and Anglo-American economic geography. Our plea for a re-conceptualization of economic geography, thus, addresses a wider audience within Anglo-American geography. Already in the 1980s, Clark (1983) has presented an early version of a relational perspective based on his analysis of labor market dynamics. This study demonstrates from within the Anglo-American context that neoclassical models of discrete exchange are not capable of explaining rigidities in local labor markets. As a consequence of this, Clark (1983) suggests a relational view of contracts which does not exclusively focus on economic exchange but also includes social elements. He particularly refers to the interdependencies of unilateral power (e.g. that of a single party based on laws and regulations) and bilateral power (i.e. based on negotiations between two or more parties), with the latter being built upon the former in a contingent manner. This conceptualization also requires a consideration of the specific context within which labor markets operate (Clark, 1982). 
The conclusions which we draw from this discussion serve as a basis for the development of a novel analytical framework which we refer to as relational economic geography (Bathelt and Glückler, 2000, 2002a, 2002b). ${ }^{3}$ We believe that the current changes in economic geography do not unfold incrementally to the extent that existing concepts are simply being improved or updated. Since the late 1980s, a wealth of new perspectives, methods and conceptions has developed that involves compelling ideas to be used as a basis of a re-conceptualization of economic geography. The implications of this are so fundamental that we treat them as paradigmatic and view them as constituting the second transition ${ }^{4}$ of the discipline: (i) We call it a transition because paradigmatic shifts are neither incommensurable nor do they occur abruptly. They evolve as phases of intense dialogue between different perspectives yielding new arguments which, in turn, become the impetus for a transition towards a new perspective. Over time, this gains dominance based on consensus and 'good reason' (Toulmin, 1972). (ii) We refer to it as the second transition because it follows a first major transition in Germany from Länderkunde to regional science and characterizes another transition from regional science to a new paradigm which we refer to as relational economic geography.

${ }^{3}$ In suggesting this framework, we do not intend to proclaim a new, relational turn in economic geography which emphasizes some aspects while neglecting others. The proclaimed cultural, social, economic, political and institutional turns from recent years have unnecessarily served to split the discipline into exclusive sub-fields (Ettlinger, 2001). In contrast, our conceptualization aims to integrate the economic and social aspects of human action in space which are inseparably intertwined (see, also, Lee, 2002).

${ }^{4}$ Similar to our notion of the second transition, Barnes (2001) identifies a shift in post-War AngloAmerican economic geography from first-wave theory (i.e. the quantitative and theoretical revolution) towards new-wave theory (associated with the cultural turn or new economic geography). While the first approach aims at objectively formalizing an independent reality, the latter one describes an interpretative mode of theorizing which is open, critical and reflexive. In our view of relational economic geography, however, we conceptualize this shift differently from Barnes (2001). 
The stages and shifts in German economic geography have been part of larger movements and shifts within the discipline. Post-War German geography has been strongly influenced by two important paradigms, that of Länderkunde (the science of regional description and synthesis) and Raumwissenschaft (spatial science). ${ }^{5}$ Of course, as mentioned above, not all research practices can be captured by these two idealized programs. Länderkunde and spatial science have, however, substantially impacted other research practices in terms of their view of space and have influenced their particular programs, methods and objectives. Länderkunde was developed as a science of regional description and synthesis by Hettner (1927) and represents the first academic school within German geography. Hartshorne's (1939) approach of areal differentiation resembles this view. According to Hettner (1927), the primary objective of the discipline was to classify the earth into naturally-defined Landschaften (landscapes) and understand their diverse structures through a description and synthesis of its layers of different geographies, such as bio, social, economic and other geographies. The main purpose of economic geography was to analyze the spatial order of the economy and detect Wirtschaftsräume (economic spaces) to be included into the wider Länderkunde framework. Economic landscapes, formations and spaces (e.g. Lütgens, 1921; Waibel, 1933; Krauss, 1933) were identified, described and synthesized with other layers of geography. Research in economic geography was largely descriptive, listing those economic activities which take place within naturally-defined landscapes.

\footnotetext{
${ }^{5}$ In other countries, such as the U.S., similar shifts have primarily taken place within economic and
} urban geography and do not necessarily correspond with a larger movement of the whole discipline. In Germany, this was somewhat different because of the integrated nature of geography as expressed in its Länderkunde tradition. 
Much later than in Anglo-American geography, this research program was criticized and challenged by new ideas from spatial science. This resulted in open conflict and culminated in the debates and controversies at the Meeting of German Geographers in Kiel in 1969 (Meckelein and Borcherdt, 1970, 191-232). In this critique, Länderkunde was heavily criticized for its lack of a sound epistemological basis and for having a largely ideographic, descriptive, holistic and naturalistic program. Drawing upon the work of Anglo-American spatial science (e.g. Haggett, 1965; Chorley and Haggett, 1965, 1967), which developed during the 1960s, Bartels (1968) developed a new conceptualization, i.e. Raumwissenschaft. This became the basis of a new paradigm in geography which lasted at least throughout the 1970 s and the 1980 s. $^{6}$ In the program of this science of space, mere description was replaced by analytic explanation and the naturalistic conception of space as a particular landscape by an abstract conception of space as a formal geometry (Bartels, 1970; Bahrenberg, 1972).

In economic geography, this first transition gave rise to Raumwirtschaftslehre (Schätzl, 1998), i.e. regional science (or spatial analysis). ${ }^{7}$ Its research program was strongly impacted by Isard's $(1956,1960)$ influential work in American economic geography. In the late 1950s, Isard $(1956,1960)$ established regional science as science of spatial order and organization of the economy and drew attention towards theories and models in neoclassical economics (von Böventer, 1962). Economic theories were incorporated into economic geography through the integration of spatial variables, i.e. the cost of transit and transport over distance. It was the objective of regional science to develop general theories and models of the spatial order of

\footnotetext{
${ }^{6}$ Unlike in the U.S., Marxist approaches did not gain much importance in postwar geography in Germany. Although many German geographers were aware of the work of Harvey (1982), it was not quoted and reflected upon in influential economic geography textbooks (e.g. Schätzl, 1998).

${ }^{7}$ We use the term regional science (or spatial analysis) to refer to those views of economic geography which are associated with the quantitative and theoretical revolution and which took place in the late 1950s and the 1960s in American geography.
} 
the economy. Location patterns, trade relations and processes of agglomeration were typically explained using spatial parameters, such as distance, catchment areas and their economic equivalents (Voppel, 1999).

In the following section, we illustrate some of the analytical and methodological limits of the regional science approach through the use of two simplified examples. From this, we develop some ideas for re-conceptualization. Section 3 lays out the foundations of an alternative research design for economic geography which is based on a relational perspective of economic action. Related to recent work in economic and social geography, we discuss the fundamental dimensions of a relational economic geography. This also incorporates ideas from critical realism. We suggest this framework as an alternative to regional science. Section 4 discusses a recent conceptualization by Storper (1997a, 1997b) in which he formulates the foundations and goals of economic geography. Drawing from this reformulation, we introduce four core concepts or ions of analysis in economic geography in section 5, i.e. organization, evolution, innovation and interaction. They are conceptualized as relational categories for a novel economic geography (Bathelt and Glückler, 2002a, 2002b). We apply this conceptualization to those areas of economic geography that we are familiar with through our own personal experience. However, we would like to invite others to try to use this conceptualization in other areas of economic geography. Section 6 summarizes our main arguments and draws some concluding remarks.

\section{Limits of Regional Science and Ideas for Re-conceptualization}

Since the late 1980s, a new set of ideas, conceptualizations and models has been published which have come to form a counterweight against the regional science approach in economic geography. This work is characterized by contrasting perspectives and enlarged complexity in the analysis of economic and social processes compared to that in regional science. Much of the critique expressed in this work can be illustrated through the simplified 
examples discussed below (for further examples of methodological problems in regional science, see Sayer, 2000). ${ }^{8}$

\subsection{Example 1: Spatial Characteristics and the Acting Region}

A classical research focus of regional science is to explain why some regions grow faster than others. In order to provide an answer to this question, a number of consecutive stages are conducted in a spatial analysis. First, spatial characteristics are identified, such as indicators of the regional infrastructure, labor force and other resources, as well as cost factors, such as wage levels. In the second stage, statistical analyses (e.g. correlation and regression analysis) are conducted to reveal which features are typical for both growing and shrinking regions. Often, causal mechanisms are derived from this analysis. It is argued, for instance, that low regional costs stimulate high regional growth. A major problem of this approach is that regions are treated as if they were the economic actors themselves having their own particular characteristics. One policy conclusion which often results from this view is that regions should lower their costs in order to stimulate growth.

However, such an argument neglects the fact that regions are not real actors. They are socially constructed entities, dependent on the particular economic, social, cultural and political settings and realities under which people in firms and other organizations act and interact (e.g. Maskell, 2001). Sometimes, even one large dominant firm might cause regional growth or decline simply through its linkages with other regional agents (Romo and Schwartz,

\footnotetext{
${ }^{8}$ We are aware that these examples provide a simplified view of regional science; i.e. one, which does not deal with all aspects and complexities of this literature. Our intention is not, of course, to deny the historical importance of this work and its path-breaking findings. In empirical studies, the contrast between regional science and relational economic geography may not always be that evident at first sight. We think, however, that the paradigmatic reconstruction that we draw is helpful to identify those problems and dimensions which are in need of re-conceptualization (for a more nuanced history of approaches in economic geography, see Scott, 2000).
} 
1995). This might be a consequence of a change in the firm's overall global market strategy and may not be related to the actual locational characteristics identified in the region (e.g. Schamp, 2000). Massey $(1985,11)$ has criticized the inappropriateness of this science of the spatial as follows: "There was an obsession with the identification of spatial regularities and an urge to explain them by spatial factors. The explanation of geographical patterns, it was argued, lay within the spatial. There was no need to look further. ... This is an untenable position. ... There are no such things as purely spatial processes; there are only particular social processes operating over space."

\subsection{Example 2: Location Analysis and Spatial Incentives}

Another focus of regional science is the analysis of spatial distributions and location decisions (Isard, 1956; Bartels, 1988; Schätzl, 1998). The location analysis of a sector involves a particular methodology. In the first stage, the locational requirements of the firms of this sector are listed. In the next stage, location factors and particular features of each region are identified. Finally, the locational requirements of the firms and the locational characteristics of the regions are systematically compared with one another to find the best match. The assumption behind this approach is that firms, in order to maximize their profits, choose exactly that location which can satisfy their requirements best, based on its inherent characteristics.

In this example spatial attributes are again used as explanatory variables which are supposed to explain location decisions and spatial distributions. Barnes $(2001,550)$ refers to these practices in quantitative regional science as fetishization because "the social processes that actually produce such figures are hidden". Also those aspects of social power which lay behind quantitative representations remain concealed. In contrast, recent work in economic geography has come to realize that firms do not just act according to spatial attributes but that they themselves create such spatial attributes in the first place (Scott, 1998). In their model of 
geographical industrialization, Storper and Walker (1989) deal with the question of how industries create their respective regions through the regular training of employees, recruitment of expertise from outside, support of newly established suppliers, outsourcing to other local suppliers and services and learning processes with near-by customers. In this view, spatial structures are seen as being socially constructed. They result from complex interactions between regional actors and groups of actors, such as firms. Through the process of reflexive knowledge-creation, the localized structures, in turn, exercise an influence on economic decision-makers and their respective actions and policies (Storper, 1997a).

Recent work in economic geography, such as that of Amin (1994), Lee and Wills (1997), Barnes and Gertler (1999), Bryson et al. (1999), Sheppard and Barnes (2000) and Clark, Feldman and Gertler (2000), has resulted in new approaches and ways of thinking which contrast with the traditional regional science view. ${ }^{9}$ One could argue that the new views and approaches do not yet establish a well-defined, fully-coherent theoretical framework (e.g. Barnes, 2001). What these studies share, however, is a critique of the traditional approach and a strong interest in understanding localized economic and social processes. In addition to economic theory, social theories and conceptualizations are also applied in these approaches to explain localized economic phenomena as an expression of both the economic and the social. From these trends, we argue for a comprehensive transition in economic geography towards a relational conceptualization which we aim to characterize in the next sections.

\footnotetext{
${ }^{9}$ The approach suggested in this paper might, however, not be the only alternative to regional science (for different paths, see Webber and Rigby, 1996; Sheppard and Barnes, 2000). It is, however, well-suited to overcome some of the shortcomings of the regional science approach and integrate a large number of studies from the 1980s and 1990s which have moved away from regional science.
} 


\section{Research Design for a Relational Perspective}

The second transition is characterized by a reformulation of the core concepts of economic geography. In the following sections, discontinuities between relational economic geography and regional science will be identified according to five dimensions of the research design. These dimensions include the conception of space, object of knowledge, conception of action, epistemological perspective and research goal. From this, we develop a relational framework for analysis which systematically focuses on economic actors and their action and interaction. The basic propositions of this framework will be developed in the remainder of this section (Figure 1).

\subsection{Conception of Space}

A relational view of economic geography is based on a relationship between space and economy which is contrary to that of regional science. ${ }^{10}$ Specifically, regional science views space as a container which confines and determines economic action. It treats space as a separate entity which can be described and theorized independently from economic action. In contrast, a relational approach assumes that economic action transforms the localized material and institutional conditions of future economic action. Similar to Storper and Walker (1989), this approach emphasizes that the economic actors themselves produce their own regional environments. The way in which spatial categories and regional artifacts have an impact on economic action can only be understood if the particular economic and social context of that action is analyzed (Bahrenberg, 1987). Spatial structures and processes have, however, been socially and economically under-conceptualized in regional science. We contend that space can neither be used as an explanatory factor for economic action nor be treated as a separate

\footnotetext{
${ }^{10}$ This shift in causality between space and human action has also been emphasized in human geography (Werlen, 1993; 1995; 2000).
} 
research object in isolation from economic and social structures and relations. Consequently, as space is not an object of causal power to explain social or economic action it cannot be theorized (Sayer, 1985; Saunders, 1989; Hard, 1993). ${ }^{11}$ Of course, economic processes also have material outcomes (e.g. infrastructure) which are localized in certain places and territories and exist over longer time periods. Of course, such structures clearly have an impact on economic action and interaction in these localities.

Nonetheless, economic actors and their action and interaction should be at the core of a theoretical framework of economic geography and not space and spatial categories. Spatial scientists, such as Bunge (1973), treat spatiality as the object of knowledge in economic geography. They aim to detect those spatial laws which govern human action without looking at the actors themselves. Instead of treating space as a container, we suggest a conception of space as perspective (Glückler, 1999). In other words, we use space as a basis for asking particular questions about economic phenomena but space is not our primary object of knowledge. It is this conception that we refer to as the geographical lens. As part of this, economic exchange becomes the focus of analysis and not space. Similarly, we do not seek to identify spatial laws but, instead, look for explanations of localized economic processes and their consequences. ${ }^{12}$

${ }^{11}$ One could argue that the economy, like space, is also a social construct and yet we have economic theories. Why then should there not also be spatial theories? The key to this question lies within the very nature of relational action. There are economic agents which develop strategies and act according to economic and non-economic goals. Their action and interaction has intended and unintended spatial outcomes. There are, however, no spatial agents which act according to spatial goals. Intentions for actions derive from the actors, not from spatial representations.

12 The term 'localized' does not imply that all economic action is locally or regionally bound but, instead, physically materializes in place. All action and interaction takes place somewhere; for instance, within particular places, regions, nations and trading blocks but also between them. The key is that economic action includes people in some places and excludes others. Because any economic activity takes place somewhere, it 
It is particularly through the application of a distinct perspective to the study of an object of knowledge that discipline-specific research problems can be formulated. The spatial perspective or geographical lens leads economic geographers to pose research questions about an economic phenomenon, different from those typically asked by economists or sociologists. We also suggest that the perspective applied helps mobilize a particular terminology and, over time, a set of tacit knowledge which entails an understanding of what it is that is being analyzed and how this subject matter can be described and evaluated adequately.

A brief example may help to illustrate the idea of the geographical lens. Depending on the disciplinary perspective used, observing changes in a firm's division of labor due to a structural crisis may cause researchers to formulate different sets of questions: A sociologist would, for instance, focus on the consequences of this crisis on the distribution of responsibilities and competencies within the work organization. In contrast, an economist may analyze the effects of this crisis on the firm's strategy, production program or new market opportunities. An economic geographer would employ a particular spatial perspective and thus typically investigate different aspects and consequences of this crisis. Through her geographical lens, she would for example analyze the impacts of this on the local labor market, supplier relations or the division of labor between different sites and locations. Of course, this example is a simplification. The point is that each perspective can shed some light on parts of a phenomenon but necessarily neglects other issues. Any research findings

necessarily interacts with other economic and social processes which take place in the same places. This is because the same agents participate in various processes at the same time and because different processes, in part, involve the same group of agents. It is therefore not that easy to isolate a particular process and neglect others. Processes are necessarily interdependent, either because they take place within the same region or exactly because they do not. It is exactly this fundamental spatial overlap of a multitude of social and economic processes that our geographical lens aims to capture. 
which result from the use of a particular perspective can themselves be used as a point of departure for new research applying a different perspective. Thus, a sociologist might use the results from a geographer's study on the localized consequences of the labor market to develop further research questions about social inclusion or exclusion. An economist, in turn, might investigate it in terms of welfare and efficiency effects and so forth. This exemplifies that space is not, in and of itself, the object of knowledge in economic geography.

\subsection{Object of Knowledge (or Research Object)}

In contrast to regional science, a relational approach does not accept the space-economy, spatial systems or spatial categories as being the core focus of a research program in economic geography. Instead, economic action and interaction are the central object of knowledge in the analysis. Thrift $(2000,698)$ has criticized a lack of explanation in traditional economic geography and demands that “... economic geographers cannot just be tied to the locational dimension as under-labourers for economists, noting down the 'wheres' whilst economists do the "whys'." Consequently, any analysis in relational economic geography is based on an understanding of the intentions and strategies of economic actors and ensembles of actors and the patterns of how they behave. Economic action is viewed as being embedded in structures of social (and economic) relations and is thus conceptualized as a context-specific process. Research in relational economic geography thus focuses on processes, such as institutional learning, creative interaction, economic innovation and interorganizational communication, and investigates these through a geographical lens, rather than uncovering spatial regularities and structures. Economic processes and relations broadly defined are at the heart of this approach which integrates (and requires) both economic and social theory. 


\subsection{Conception of Action}

Similar to neoclassical economics, regional science employs an atomistic view of economic agents (for a discussion of agency and space, see Sheppard, 2000). Often, economic agents are seen to act in isolation from other agents and their institutional environments according to the rationale of a homo economicus. In contrast, a relational framework emphasizes the importance of contextuality of human action. Economic action is embedded in structures of ongoing social relations (Granovetter, 1985; Grabher, 1993).

From the view of the geography of the firm, this means that firms are not independent entities but are closely interconnected in communication and adjustment processes with their suppliers, customers and institutions and must be analyzed accordingly. ${ }^{13}$ An atomistic view of economic agents thus leads to a very limited understanding of their activities as context is neglected (Granovetter, 1992b). The socio-institutional context creates opportunities for economic action and interaction that would otherwise not exist. From these opportunities, agents develop new goals and strategies for action. A relational approach in economic geography thus systematically includes context into its research program. ${ }^{14}$ As a consequence

${ }^{13}$ Maskell (2001) has criticized that traditional economic geography often treats firms like a 'black box'. To overcome this he suggests the use of a resource-based or competence-based view of the firm (see, also, Wernerfelt, 1984; Prahalad and Hamel, 1990). Nonaka, Toyama and Nagata (2000) explicitly include the particular role of knowledge and develop this further into a knowledge-creation view of the firm. These views correspond nicely with a relational perspective of economic action as portrayed in this article.

14 This is particularly important when analyzing the growing importance of knowledge within the economy (Lundvall and Johnson, 1994). Knowledge is context-specific and bound to people. In order to understand the process of knowledge-creation, it is necessary to understand how people act and interact with one another (Bathelt and Glückler, 2000). New knowledge is being created through interactive processes of interpreting, integrating and transforming existing knowledge within a specific context. Nonaka, Toyama and Nagata (2000) use the Japanese notion of 'ba' to refer to the organizational context of knowledge-creation, related to the particular time and place where interaction occurs. 
of this, particular attention is paid to economic action as a social process and the structure of relations between agents and the creation of formal and informal institutions. ${ }^{15}$ In sum, economic action is a process, situated in time and place (Philo, 1989; Giddens, 1990; Martin, 1994; 1999; Sunley, 1996; Bathelt and Glückler 2002a, 2002b; Glückler, 2001).

\subsection{Epistemological Perspective}

Since human action is viewed as contextual, it cannot be explained by universal laws. Action in open systems is not fully predictable and, thus, cannot be adequately conceptualized through deterministic theory (see, also, Peck, 1996). This is, however, what approaches in regional science aim at when they apply existing or identify new spatial laws and regularities of economic action. In contrast, critical realism provides a fundamentally different epistemological perspective of causality in that it systematically accounts for context-specificity in human action (Archer et al., 1998). ${ }^{16}$ Critical realism was developed by

15 The role of institutions in shaping the context of economic agents has been recognized in much of the recent literature on innovations. Institutional contexts which are determined at the level of the nation-state, such as the educational and research infrastructure, work rules and organizational standards with respect to social division of labor and the like, have a substantial influence on the nature of economic problems and shortages identified and the learning processes applied. As a result, particular national systems of innovation develop (Lundvall, 1992; Nelson, 1993). In these systems, institutions have a strong impact on interaction and innovation and, thus, shape the national production structure. The production structure, in turn, strengthens and reshapes existing institutions and develops them further, thus driving national specialization patterns (Lundvall and Maskell, 2000). Even further, such approaches need to consider aspects of cultural context, difference, 'othering' etc. in order to explain different production patterns more carefully (e.g. Saxenian, 1994; Schoenberger, 1997; Thrift, 2000).

${ }^{16}$ Critical realism is not necessarily the only methodological alternative towards a relational economic geography (see, also, Harvey, 1996). It provides, however, a particularly well-suited conceptualization to integrate the key concepts 'context' and 'contingency' into a coherent framework which allows to overcome a 
the British philosopher Bhaskar (1975) and propagated in the social sciences by Sayer (1992, 2000). It serves as a pragmatic epistemological alternative which attempts to avoid the problems of both deductive-nomological determinism in logical empiricism and relativism in postmodern theory (Lovering, 1989; Thrift, 1990; Sayer, 2000). In contrast to postmodern approaches, critical realism maintains the assumption that an objective reality exists which is independent from the individual. The relation between reality and human knowledge about it is, however, asymmetrical. The fact that empirical observations are necessarily mediated through concepts does not imply that they are a product of these concepts only. Instead, these observations are also dependent on the structural properties of the real objects (Sayer, 2000, 41). Critical realism also aims at developing causal explanations for general mechanisms. In contrast to positivist approaches, however, causality is no longer implied from their universal co-occurrence.

Conventional causal analysis as employed in regional science is based on Hume's (1758) principle of regularity. In this principle, an event is the cause of another subsequent event, if its occurrence is always associated with the occurrence of the latter event. Constant conjunction here is used as an associative principle of causality (Sayer, 2000). This explanation claims to be universal for it assumes that an event has particular consequences which occur at any time and any place in association with this event. In contrast, critical realism establishes a contextual explanation based on the principle of contingency. This approach distinguishes two types of relations between events (Sayer, 1985):

(1) Necessary relations. Relations are necessary, if two events always occur in association with one another, independent from a specific context. Such non-contextual relations or universal laws are, however, extremely rare in social and economic processes (Fleetwood, 2002). 
(2) Contingent relations. Relations are contingent, if two events occur in conjunction with one another only under specific circumstances. Such relations are quite typical in the analysis of economic action using a geographical lens.

The principle of contingency states that one event does not necessarily cause another particular event. Therefore, identical preconditions for human action do not necessarily have the same consequences at any time and place. This provides an epistemological basis for a context-specific conceptualization of the intentions and consequences of human action. At the same time, it is recognized that future actions and development are fundamentally openended. ${ }^{17}$ Contingency, however, does not result from human action alone, but also arises from differences in the localized material structure, as well as from variations between places and territories in the institutional architecture. ${ }^{18}$ This creates deviations between regions, nations, etc. and results in different sets of opportunities and restrictions for economic action. Overall, this leads to particular structure-agency dynamics. ${ }^{19}$

${ }^{17}$ One could argue that the inclusion of stochastic processes in regional science also allows for openended, contingent development (e.g. Curry, 1967; Cliff et al., 1981). While this is certainly the case we would like to emphasize that this is a more formalistic view of contingency which does not provide a closer insight into the nature of economic action and interaction at work.

${ }^{18}$ Particularly during the 1980s and early 1990s when 'new' regional configurations of industrial districts and industrial spaces were discovered and discussed, this encouraged researchers and policy makers, at least implicitly, to seek for general models of regional development. In a way, this was like searching for universal forms and general laws of spatial economic development and, thus, created similar problems to those of some earlier regional science work. We owe this argument to one of the reviewers.

${ }^{19}$ Contingent action reproduces or transforms specific contextual structures which, in turn, shape the preconditions for future action. In this respect, context is related to structure and contingency associated with agency or, as Jessop (1992) would say, strategy. The resulting interdependence between contextual structure and contingent action corresponds with those reflexive mechanisms at the heart of structuration theories, as developed by Giddens (1984) and Bourdieu (1977). 
The application of this concept does not mean, however, that research ends with a contextual explanation of singular events in particular locations and circumstances at a given time. Instead, another important step of realist analysis is to go beyond individual events and their specific contexts in order to identify common aspects of the causal mechanisms that affect economic action. This involves the identification of the causal mechanisms which are at the heart of localized economic action and interaction as opposed to the formulation of spatial laws. This methodology aims to uncover basic conditions of specific contexts and relate them to others. In this way, de-contextualization provides a methodology to identify trans-contextual, more-or-less necessary circumstances and structures from contextualized events.

\subsection{Research Goal}

Relational economic geography explicitly draws attention to the importance of economic agents and how they act and interact in space, instead of focusing on the description of spatial categories, processes and regularities. This has been accomplished through the application of the following changes to the research design: First, this has been achieved by inverting the causality between space and economy and adopting a conception of space as perspective (i.e. the geographical lens). Second, this approach views economic action as a relational process which is situated in structures of relations. Third, the principle of contingency has been introduced into the analysis of causal relations to establish an epistemological basis which accounts for contextual action and development. The objective of relational economic geography is to formulate research questions which are associated with the analysis of economic relations using a geographical lens (Bathelt and Glückler, 2002a, 2002b). 
The transition from regional science towards a relational approach, which we have aimed to illustrate in this section, has fundamental consequences for analysis in economic geography. It rests on three propositions:

(1) Contextuality. From a structural perspective, economic agents are situated in contexts of social and institutional relations (Granovetter, 1985; 1992a, 1992b). Since this conceptualization views action as being embedded in specific contexts, it cannot be explained through the application of universal spatial laws.

(2) Path-dependence. From a dynamic perspective, contextuality leads to pathdependent development because yesterday's economic decisions, actions and interactions enable and constrain the context of today's actions. They also direct future intentions and actions to some extent (Nelson and Winter, 1982; Nelson, 1995).

(3) Contingency. Economic processes are at the same time contingent in that the agents' strategies and actions may deviate from existing development paths. Economic action in open systems is not fully determined and cannot be predicted through universal spatial laws. Despite its path-dependent development which provides a particular history, economic action is subject to unforeseeable changes and is therefore fundamentally open-ended (Sayer, 1992, 2000).

Relational economic geography enables a complex understanding of economic action and its localized consequences. It focuses on those people, firms, institutions and other organizations which are involved in economic decision-making, as well as on those people and environments which are subject to the consequences of economic action. This relational perspective does not intend to identify spatial regularities and avoids treating regions and other spatial configurations as actors. Instead, the strategies and objectives of economic 
agents and their relations with other agents and institutions are the core of the analysis. ${ }^{20} \mathrm{~A}$ contextual, path-dependent and contingent perspective is quite different from other theoretical programs which view economic geography in line with universal laws, linear developments and closed systems. Therefore, a transition from regional science to relational economic geography requires a reformulation of the concepts used to understand economic structures and processes. In the following sections we lay out the basic propositions and concepts of an alternative framework for economic geography.

\section{Storper's Conceptualization of the Holy Trinity}

The most sophisticated attempt to reformulate the foundations and goals of economic geography is that developed by Storper (1997a, 1997b). His conceptualization of the holy trinity in economic geography serves as our reference and point of departure. We integrate his ideas into a general model of relational action and interaction as a basis for a reconceptualized economic geography (Bathelt and Glückler, 2002a, 2002b).

Storper $(1993,1997 \mathrm{c})$ argues that localized production systems continue to play a decisive role in the global economy despite revolutionary improvements in information, communication and transportation technologies. He suggests that this continued importance of proximity is due to the advantages from reduced transaction costs and enhanced capabilities for organizational and technological learning in specialized agglomerations of interrelated economic activities. Apart from traded interdependencies, which are the key

\footnotetext{
${ }^{20}$ The use of regression analysis provides a good example to illustrate the problems with context and contingency in regional science. The use of such tools is based on the assumption that the same conditions always result in identical outcomes (i.e. one particular value of the explanatory variable necessarily produces the same estimate of the dependent variable over and over). However, reality is different from this. Firms which operate under similar conditions in the same sector and region might pursue rather different strategies because they are embedded into a different market logic and context.
} 
variables in the regional science literature, untraded interdependencies play a decisive role to enable communication, adjustment and learning processes between economic agents (Storper, 1997a). They are embodied in the role of relations between particular people and the existence of conventions as expressed in accepted norms, rules and practices. Relations and conventions are also localized because they are bound to those people, firms and places involved and cannot easily be transferred to other places. They become region-specific assets and form the basis for further concentration and specialization of economic activities (Maskell and Malmberg, 1999a, 1999b).

To understand the complex nature of economic production and its geography, Storper (1997a, 1997b) identifies technology, organization and territory as overlapping constituent pillars of economic geography. They form a holy trinity through which economic and social processes and their interactions and power relations can be analyzed. ${ }^{21}$ This holy trinity serves as a conceptualization of economic geography radically different from regional science (Figure 2): (i) Technology. Technological change lies at the heart of the dynamics of the economy. It results in the rise of new and the decline of old products and processes. (ii) Organization. This pillar emphasizes the importance of the ways in which firms and networks of firms are organized and how these organizational structures are impacted by institutions. (iii) Territory. At the territorial level, it is possible to analyze the co-evolution of organizations and technologies. Through regional input-output linkages, knowledge transfers and adjustments between firms, spillover effects and learning processes occur which enhance the collective competitiveness of those regional agents which are interrelated in the same value chain. Therein, untraded interdependencies play a decisive role in transforming technological and organizational worlds into regional worlds (Storper, 1993, 1997a).

\footnotetext{
${ }^{21}$ Crevoisier (2001) uses a similar conceptualization when analyzing creative milieus through the complex interrelationships and dynamics of co-existing technological, organizational and territorial paradigms.
} 
An important aspect of Storper's $(1995,1997 a)$ approach is that he emphasizes the role of context-specific institutions. He also views social interactions, as expressed in processes of organizing, learning and knowledge-creation, as being central to analyses in economic geography. Storper (1997a, 1997b) identifies mechanisms through which socio-institutional contexts stimulate processes of geographical clustering of industrial production and provides an explanatory framework which concentrates on economic agents as opposed to their spatial settings. We believe, however, that this conceptualization also bears the risk for misinterpretations with respect to its implicit spatial foundations:

(1) Overemphasis of the spatial dimension. In Storper's (1997a, 1997b) holy trinity, the territory forms a pillar of its own in addition to the dimensions of organization and technology. This implies that the three have the same status and importance within this conceptualization of economic geography. We suggest that it is necessary to exercise care in this respect and not to treat economic and social processes in a similar way as spatial processes. While organization and technology can be conceptualized in a meaningful way, the metaphor of territory could provide a temptation for regional science-based interpretations which try to develop theories of space, in the way criticized by Massey (1985). We suspect this is not Storper's (1997a, 1997b) intention. Instead of using the concept of territory as a constituent pillar of economic geography, we conceptualize space as perspective (Glückler, 1999). This perspective serves as a geographical lens which guides the analysis of economic and social processes in economic geography (Bathelt and Glückler, 2002a, 2002b).

(2) Isolation of the geographical perspective from the economic and the social. The conceptualization of territory as a separate pillar of economic geography is associated with further disadvantages. It serves to restrict the analysis of spatial processes and structures to a single analytical dimension, as well as its overlapping areas with those of other dimensions. This could lead some to view organization and technology as abstract dimensions which are not localized. To avoid such interpretations, we build our conceptualization of economic 
geography around the geographical lens because it enables us to contextualize all processes from the very beginning of our analysis. In this conceptualization, territory can hardly be treated as a separate entity.

\section{Four Ions of a Relational Economic Geography}

In this section, we aim to develop the criticisms, new ideas and approaches mentioned above into a novel, relational framework for analysis in economic geography based on Storper's (1997a, 1997b) conceptualization of the holy trinity. This framework revolves around the basic concepts of organization, evolution, innovation and interaction. We refer to these as the four 'ions' of a relational economic geography. These concepts are founded on the relational perspective developed above. In our conceptualization, social institutions are of great importance in understanding and explaining context-specific behavior and action. We refer to numerous institutional concepts, such as those discussed by Storper (1997a), Schamp (2000) and others. They help to understand the mechanisms through which all ions are being constructed and reconstructed and serve as basic mechanisms to develop our relational framework.

The point of departure of our conceptualization is that those economic and social processes which drive the four ions are to be analyzed and evaluated using a distinct geographical lens (Figure 3). This allows us to develop an interdisciplinary approach to economic geography which integrates both economic and social theories. In the following sections, we will indicate which research problems are associated with each of the ions. In applying a geographical lens, we will also demonstrate that these ions are closely interrelated with one another (Bathelt and Glückler, 2000, 2002a, 2002b). The structure of the four ions, which is employed in Figure 3, serves as a heuristic framework to systematically apply the 
consequences of a relational perspective to the theoretical debates in much of the work of economic geographers today, particularly with respect to the geography of the firm. ${ }^{22}$

\subsection{Organization}

A basic problem of organizing industrial labor and production processes is to establish an efficient division and integration of labor (Sayer and Walker, 1992). This involves the coordination of the labor force, raw materials, intermediates, machinery and equipment applied within and between workplaces and firms. In essence, it includes the establishment of a particular social and spatial division and integration of labor. This has to be done in such a way that sufficient control can be exercised over the production process to continuously produce the same goods at high quality standards according to customer needs (Bathelt, 2000). To solve the problem of industrial organization, decisions have to be made with respect to which process technologies will be used and the way in which the labor and production stages will be bundled together. This also includes decisions regarding which intermediate products will be produced in-house and which will be acquired from subcontractors and suppliers. If some vertical disintegration is intended, which is usually the case, the next question to be answered is which suppliers from which regions will be contacted, which competencies they will be given and in which places, regions and nations what parts of the production chain will be located. These and other aspects of industrial

\footnotetext{
${ }^{22}$ The relational perspective proposed in this paper suggests that the research questions asked are
} themselves contextual, depending on the context of a particular discipline focus. Here, the geography of the firm (Dicken, 1990) serves as an example to demonstrate the consequences of a relational approach. This also means that a different pattern of ions could result if another discipline focus was applied. Different contexts might, for instance, be derived from feminist, labor market or political economy literatures (for interesting accounts, see McDowell, 2000; Peck, 1996; Harvey, 1982; 1996). 
organization can be analyzed through the application of institutional theories, such as the transaction cost approach in economics (Coase, 1937; Williamson, 1975, 1985) and the embeddedness approach in social sciences (Granovetter, 1985, 1992a, 1992b).

A firm's particular solution to this organization problem has a direct impact on the locational structure of the firm and the spatial organization of its production. In turn, the spatial distribution of potential suppliers and customers, as well as the strategies and decisions of major competitors, also have an impact on the resulting social and spatial division of labor. Overall, the organizational problem of industrial production is so complex that it is not possible to explain its outcome simply through the use of location factors and regional attributes. Spatial proximity and institutional affinity (or proximity) can in some technological and political contexts help to stabilize network relations between specialized firms because they reduce information costs, generate information spillovers and enable more efficient communication (Scott, 1988, 1998). Depending on the institutions which shape industrial relations and organization, the existing training and education system and other aspects of the capital-labor nexus, regional or national agglomerations can result.

These organizational structures are, however, not static ones. An evolutionary perspective is required to understand the dynamic nature of the organization of firms and value chains as a result of socio-institutional relations and their changes (Nelson and Winter, 1982; Swedberg and Granovetter, 1992). Whether a firm develops a vertically-integrated production structure or whether it engages in vertical disintegration and, if so, in which regions subcontracting relationships will be established also depends on its experience and the particular sequence of organizational decisions made in the past. Learning from experience results in enhanced organizational reflexivity.

At the same time, organizational structures are embedded in social, cultural and institutional structures and relations which cannot be separated from the economic sphere. The existence of accepted rules, habits, norms and other institutional arrangements creates a 
reliable environment for interactive learning (Hodgson, 1988; North, 1991) and has a direct impact on the organization of innovation and production processes. The organizational structure of a firm and its development is also related to formal institutions and authorities which create societal standards and laws (e.g. Baum and Oliver, 1992). Therefore, the spatial organization of production is a result of complex negotiations and temporary compromises between firms and formal institutions and authorities and takes place within the context of particular power relations (e.g. Taylor, 1995; Allen, 1997; Berndt, 1999).

\subsection{Evolution}

The evolutionary dimension ${ }^{23}$ is of great importance because it allows for the analysis of the impact of historical structures and processes on today's decisions. Evolutionary concepts of change assume that economic and social processes are experience-based, cumulative and reflexive in nature. They are path-dependent in that they follow particular histories of decisions, actions and their consequences. In this respect, there is a remarkable convergence of evolutionary perspectives in economics, sociology and economic geography (Bathelt and Glückler, 2000).

Evolutionary economics supposes that techno-economic change defines a development path which follows particular routines and heuristics (Nelson and Winter, 1982; Dosi, 1982;

\footnotetext{
${ }^{23}$ The inclusion of this ion does not, of course, imply that we prioritize time over space. Even though both are treated in a similar way, the spatial perspective serves as a key concept for analysis in economic geography to relate all ions to one another. Despite its importance, the evolutionary dimension has often been neglected in neoclassical economics and regional science. We are aware, however, that early antecedents of evolutionary thinking exist, such as Myrdal's (1957) and Hirschman's (1958) work on cumulative causation in regional development and Kaldor's (1970) contribution on the role of increasing returns in regional development paths, albeit that this work does not reflect the relational approach presented here.
} 
1988; Nelson, 1995). As part of this, the direction of technological change is pre-structured by existing technologies, albeit not in a deterministic way. Existing technologies are products of past decisions made about innovation and previous technologies. Through this, processes of selection, mutation, variation and chance are initiated which aim at the creation of knowledge and new technologies to increase efficiency. Past choices generate potentials for present actions and at the same time limit the set of feasible solutions because old decisions cannot be easily reversed.

New approaches in economic sociology have extended this techno-economic view by applying aspects of socio-institutional embeddedness (Zukin and DiMaggio, 1990). Granovetter (1985) has pointed out that economic activities are deeply embedded in structures of social relations. This means that firms cannot be analyzed as independent entities but must be viewed within their respective socio-economic contexts; that is, they are closely interconnected in communication and adjustment processes with their suppliers, customers, service providers and state authorities (Grabher, 1993).

This is closely related to the role of institutions. Institutions do not only restrict the possibilities of economic action (North, 1991). More importantly, they also create a basis for mutual communication, collective learning and joint problem-solving, without which a technical and social division of labor and economic interaction would not be possible (Giddens, 1984; Hodgson, 1988). Formal and particularly informal institutions, such as conventions, accepted rules and habits, are of great significance because they invigorate and further stimulate localized production systems at different spatial levels. Embeddedness is not spontaneous but is experience-based and develops over time from a historical process. Contextual economic relations are the result of previous and ongoing experience in durable economic transactions. Through the same process, they also form the basis for future pathdependent and context-specific developments. In an evolutionary perspective, informal institutions can be materialized and transformed into formal institutions, such as laws. They 
are then typically integrated into an organizational context (e.g. a government agency) from which they are inseparable (Amin and Thrift, 1994).

Recent studies in economic geography which try to explain the rise of new industrial spaces and the process of geographical industrialization also tend to be evolutionary in their view (Scott, 1988; Storper and Walker, 1989). These studies integrate findings from evolutionary economics and the embeddedness approach into a specific spatial development perspective, albeit sometimes in an implicit way. In their model of geographical industrialization, Storper and Walker (1989) argue that novel industries have few specific locational requirements in their early growth stages. New firms are thus relatively free in their decision where to locate. This occurs because the particular inputs required do not exist anywhere and, instead, must be acquired from whatever materials are at hand. Thus, numerous regions exist which could house the industry. Later on, a handful of regions come to specialize in this industry, driving selective clustering. Due to their superior growth performance, they are able to actively shape their locational environment according to their needs. For instance, they stimulate the development of a specialized supplier sector and create a labor market which fits their particular skill requirements. The firms in these clusters thus develop a competitive advantage over those in other regions. This supports further agglomeration and specialization in the existing clusters. A more complex understanding of industrial and regional development paths and their socio-institutional contexts can be achieved if the effects of localized capabilities (Maskell and Malmberg, 1999a, 1999b) and untraded interdependencies (Storper, 1995, 1997a) are included in the analysis (Bathelt, 2002).

\subsection{Innovation}

This dimension is closely associated with processes of knowledge-creation, the development of new technologies and the effects of technological change, especially in a 
spatial perspective. Many traditional concepts in economics and geography fail to properly understand the processes of generating new products and processes and introducing innovations to established markets. Technological change is either viewed as a given, being external to the models used or portrayed as a predictable outcome of a linear research process which follows a controlled sequence of research and development stages.

More recent evolutionary interpretations, such as those of Dosi (1988) and Storper (1997a), have realized that the process of generating new technologies has to be conceptualized with care. The creation of new technologies is viewed as an interactive social process, characterized by a particular social division of labor within a firm and between different firms of the value chain, as well as between firms and universities and governmental research facilities. This process is characterized by continuous feedback from various stages in research, testing and production, reflexive patterns of economic behavior and interactive learning between the agents involved. Innovative activities are risky in that researchers do not know if they will succeed. Thus, uncertainty plagues the innovation process. Successful innovations are often associated with the creation of new or the modification of existing knowledge. The process of generating new technologies and knowledge is path-dependent in that it depends on the actors' experiences. Further, search activities are often limited to a particular class of techno-economic problem-solving mechanisms. Innovation processes of firms therefore follow particular technological trajectories in which search processes are stimulated and directed by existing routines, heuristics and cognitive scripts (DiMaggio, 1997).

The particular spatial organization of innovation depends on a number of influences. These include the degree to which production processes are vertically disintegrated, the existence of near-by firms which could become partners in innovation and the type knowledge which is needed in the innovation process, as well as the degree to which this knowledge is localized (or sticky). The spatial organization is also greatly impacted by 
experience from previous innovation processes. Many new technologies are incremental in character and have not been developed in integrated research processes in large globallyorganized firms. In addition, specialized industrial agglomerations support those innovation processes which rely on an extensive social division of labor. In this case, spatial proximity enables regular personal communication, joint problem-solving and adjustments between the people and firms involved. These interactions stimulate information spillovers and processes of knowledge-creation (Storper and Walker, 1989; Storper, 1997a; Maskell and Malmberg, 1999a, 1999b; Bathelt and Glückler, 2000). This is particularly well developed if a large number of firms of the same value chain are involved in this social division of labor and if they share the same local socio-institutional context (Crevoisier and Maillat, 1991).

Especially nation-states have a great impact on the structure of technology- and knowledge-creation because they define the primary institutional settings for the development of national innovation systems (Lundvall, 1992; Nelson, 1993). These national innovation systems are for instance characterized by different culture, organizational structures, varying degrees of vertical integration and centralization, different routines and habits in technological trajectories and distinct ways in which they enable regional adjustments to localized capabilities. At the regional level, national innovation systems are being modified and adjusted to those local cultures (e.g. Saxenian, 1994; Schoenberger, 1997), institutions and production specificities at hand and thus result in region-specific innovation and development paths.

\subsection{Interaction}

Interactions between actors and ensembles of actors in economic contexts are another crucial element of our relational framework. One important conclusion from the preceding discussion is that the particular organization of production and the processes of generating innovation are a result of ongoing interaction. This also operates as an enabling force for 
further interaction between people in various workplaces, firms and formal institutions and authorities. An evolutionary approach helps to understand how the nature and extent of interaction changes over time according to ongoing experience between those organizations involved in innovation. The processes of interactive learning, creative variation and collective knowledge-production can thus be viewed as conceptual tools which link the organization and innovation ions and generate an evolutionary dynamic. Interactions of various kinds between economic agents at different spatial and organizational levels enable firms to modify and refine heuristics and routines along existing trajectories or to develop new technologies towards new development paths.

Interaction and learning are at the core of the reflexive economy (Lundvall and Johnson, 1994). This means that the outcomes of previous actions are recorded, checked and evaluated in a systematic way in order to draw conclusions for further improvements in future actions. Indeed, empirical studies have shown that production and innovation are social processes, characterized by a particular social division of labor. This social character gains in importance as technologies become more complex and sophisticated and as specialization and segmentation increase. Through this, the process of learning by interacting has become a central issue of analyses in economics, sociology and economic geography (Lundvall, 1988; Gertler, 1993, 1995). Learning by interacting refers to a process through which systematic communication and adjustment between producers and users results in mostly incremental improvements of product and process technologies and organizational routines.

The existence and acceptance of formal institutions and particularly informal institutions are important prerequisites which stimulate interactive learning between economic agents. Routines, conventions and habits with respect to the technologies and resources used enable producers to communicate with their suppliers and customers and to collectively decide upon product and process adjustments in particular projects (Storper, 1997a). Interactive learning has also distinct consequences for the spatial organization of 
production and innovation because conventions and social relations are only preliminary, always restructured through feedback between agents. Their adjustments require the copresence of agents, which is most efficiently conducted through co-location (Storper, 1997a). Some conventions cannot be easily transferred over large distances to other social contexts (Maskell and Malmberg, 1999a, 1999b). As a consequence, industry clusters develop which are characterized by close inter-firm interaction, proximity and learning. They enable efficient information and knowledge transfers (Storper, 1995; Asheim, 1999; Bathelt, 2002). Over time, this encourages the development of shared technological attitudes and expectations between the local actors and stimulates trust-based linkages (Crevoisier and Maillat, 1991). Therefore substantial interaction still takes place within national and regional socio-economic contexts despite the development of new forms of global organization of production (e.g. Dicken, 1994; Zeller, 2001).

\section{Conclusion: Implications of a Relational Perspective in Economic}

\section{Geography}

Since the late 1980s, new ideas, conceptions and models, especially those originating from Anglo-American geography, have spread within the discipline and have initiated a reorientation of research practices in economic geography. This paper conceptualizes this as a shift towards relational economic geography which is currently taking place in numerous countries despite their different academic histories. We have begun to illustrate the occurrence of this shift in both German geography and economic geography. In German geography, we have identified this as a second transition from spatial science towards a socially-constructed, actor-centered and process-oriented geography. This followed the first transition from Länderkunde towards spatial science which took place in the late 1960s and early 1970s. In economic geography, this change can be described as a transition from 
regional science (or spatial analysis) towards relational economic geography. In reviewing the literature, we argue that this transition corresponds with a wider shift in Anglo-American economic geography (e.g. Lee and Wills, 1997; Clark, Feldman and Gertler, 2000; Barnes, 2001).

The paradigmatic differences between these conceptualizations have been laid out systematically and five dimensions in the research design identified which explicate discontinuities between the paradigms discussed. These dimensions include the conception of space, object of knowledge, conception of action, epistemological perspective and research goal. From this, a relational view of economic action has been developed which rests on three basic propositions. First, economic actors are structurally situated in contexts of social and institutional relations. Second, economic processes are path-dependent to the extent that future action is dependent on past decisions, structures and processes. Third, economic processes are at the same time contingent and open-ended in that agents make choices which may deviate from existing development paths.

Drawing on Storper's (1997a, 1997b) holy trinity, we define four ions as the basis for analysis in economic geography, i.e. organization, evolution, innovation and interaction. These interrelated concepts serve as a heuristic framework to systematically apply the consequences of a relational perspective to the theoretical debates in much of the work of economic geographers throughout the 1990s. The point of departure for our conceptualization is that those economic and social processes which drive the four ions are analyzed using a distinct geographical lens. This allows us to develop an approach to economic geography which integrates both economic and social theories. In applying the geographical lens, this allows us to formulate specific geographical research problems and implications, different from those in economics and sociology. Our conceptualization does not treat space and territory as entities which are research objects in themselves, being separate from both the economic and the social. Similarly, we do not intend to theorize space or identify spatial laws 
but look for explanations of human action in localized economic processes. Alternatively, we apply an understanding of space as perspective. This geographical lens draws our attention towards particular localized representations of economic processes and their outcomes.

Our conceptualization does not attempt to develop a comprehensive standard theory which is capable of explaining and predicting all possible outcomes of social and economic processes in space. Rather, the framework developed in this paper presents an interdisciplinary and multidimensional relational view which can be applied to a large number of research problems in economic geography, especially those that we have personally dealt with over the past decade. From a relational view, which rests on the assumptions of contextuality, path-dependence and the contingency of economic action, a standard body of theory would be a virtual impossibility anyway. Instead, we aim to uncover a novel way to help formulate research questions in economic geography, different from those in regional science (or spatial analysis), yielding subsequently different answers.

In focusing on the geography of the firm, an alternative relational view of economic geography would pose the following types of questions: How do firms interact with one another and what are the consequences for localized processes and structures? In which way are firms influenced by institutional and socio-cultural contexts in their home base and how does this change when they expand to other contexts? How are firms, networks of firms and production systems organized and how does this organization vary from place to place and which territorial consequences result from this? Through which processes do new institutions evolve and how are the localized $?^{24}$ Which interactive communication and adjustment

\footnotetext{
${ }^{24}$ One central issue on the agenda of relational economic geography is to provide a better understanding of how institutions shape contextual action, as well as the ways in which contingent action helps to transform existing and evolve new institutional forms. This is quite important because dynamic institutions continuously enable and constrain human action. Since they are sometimes territorial in character and vary
} 
processes with other firms and formal institutions allow firms to shape their environments and improve competitiveness? What are the impacts of global changes in technology, demand and competition on the organization of production and how do these effects vary between communities, regions and nations?

In our view, these questions are particularly relational for they systematically draw on the concepts of context, contingency and path-dependence of economic action and its localized consequences as a point of departure for analysis in economic geography. To answer these questions, we require a fundamental revision of traditional concepts in economic geography, such as that of the four ions which we have developed in the context of the geography of the firm. Our intention is to provide a starting point for analysis which can be further explored and applied in different contexts of economic geography.

Acknowledgements. We would like to thank Gerhard Bahrenberg, Christian Berndt, Gordon Clark, Ernst Giese, Eric Sheppard, Ute Wardenga, Benno Werlen and Clare Wiseman for their stimulating comments and constructive suggestions on earlier versions of this paper, as well as the editors of this special issue. Parts of this paper were presented at the 2001 Meeting of German Economic Geographers in Rauischholzhausen near Marburg (F.R.G.), at the 2002 Meeting of the Association of American Geographers in Los Angeles (USA) and a Geography Colloquium at University of Zurich (Switzerland). We would like to thank the participants of these meetings for their helpful remarks. We are also grateful for the thoughtprovoking comments of four anonymous referees which have helped us to clarify some of our arguments. The usual disclaimers do of course apply. Parts of this research were funded through the Deutsche Forschungsgemeinschaft (German Science Foundation).

between places, regions or nations, they are of great significance to understand different processes and structures in spatial perspective. 


\section{References}

Allen, J. (1997) Economies of power and space. In R. Lee and J. Wills (eds) Geographies of Economies. London, New York, Sydney: Arnold, 59-70.

Amin, A. (ed) (1994) Post-Fordism. Oxford, Cambridge (MA): Blackwell.

Amin, A. and Thrift, N. (1994) Living in the global. In A. Amin and N. Thrift (eds)

Globalization, Institutions, and Regional Development in Europe. Oxford, New York: Oxford University Press, 1-22.

Amin, A. and Thrift, N. (2000) What kind of economic theory for what kind of economic geography. Antipode, 32: 4-9.

Archer, M., Bhaskar, R., Collier, A., Lawson, T. and Norrie, A. (eds) (1998) Critical Realism. Essential Readings. London, New York: Routledge.

Asheim, B. (1999) Interactive learning and localised knowledge in globalising learning economies. GeoJournal, 49: 345-352.

Bahrenberg, G. (1972) Räumliche Betrachtungsweise und Forschungsziele der Geographie (Spatial approach and research goals in geography). Geographische Zeitschrift, 60: 824.

Bahrenberg, G. (1987) Über die Unmöglichkeit von Geographie als 'Raumwissenschaft'. Gemeinsamkeiten in der Konstituierung von Geographie bei A. Hettner und D. Bartels (About the impossibility of geography as a 'science of the spatial'.). In G. Bahrenberg, J. Deiters, M. Fischer, W. Gaebe, G. Hard and G. Löffler (eds) Geographie des Menschen. Dietrich Bartels zum Gedenken. Bremer Beiträge zur Geographie und Raumplanung, 11. Bremen, 225-239.

Barnes, T. J. (2001) Retheorizing economic geography: From the quantitative revolution to the 'cultural turn'. Annals of the Association of American Geographers, 91: 546-565. 
Barnes, T. J. and Gertler, M. S. (eds) (1999) The new Industrial Geography: Regions, Regulation and Institutions. London, New York: Routledge.

Bartels, D. (1968) Zur wissenschaftstheoretischen Grundlegung einer Geographie des Menschen (Towards a scientific foundation of human geography). Erdkundliches Wissen, 19. Wiesbaden: Steiner.

Bartels, D. (1970) Einleitung (Introduction). In D. Bartels (ed) Wirtschafts- und Sozialgeographie. Köln, Berlin: Kiepenheuer \& Witsch, 13-45.

Bartels, D. (1988) Wirtschafts- und Sozialgeographie (Economic and social geography). Handwörterbuch der Wirtschaftswissenschaft, 9. Stuttgart, New York: Fischer; Tübingen: Mohr (Siebeck); Göttingen, Zürich: Vandenhoeck \& Ruprecht, 44-54.

Bathelt, H. (2000) Räumliche Produktions- und Marktbeziehungen zwischen Globalisierung und Regionalisierung - Konzeptioneller Überblick und ausgewählte Beispiele (Spatial production and market linkages in global and regional contexts - concepts and realities). Berichte zur deutschen Landeskunde, 74: 97-124.

Bathelt, H. (2001) Warum Paul Krugmans Geographical Economics keine neue Wirtschaftsgeographie ist! Eine Replik zum Beitrag 'New Economic Geography’ von Armin Osmanovic in DIE ERDE 131 (3): 241-257 (Why Paul Krugman's geographical economics is not a new economic geography! A reply to 'new economic geography' by Armin Osmanovic). Die Erde, 132: 107-118.

Bathelt, H. (2002) The re-emergence of a media industry cluster in Leipzig. European Planning Studies, 10: 583-611.

Bathelt, H. and Glückler, J. (2000) Netzwerke, Lernen und evolutionäre Regionalentwicklung (Networks, learning and evolutionary regional development). Zeitschrift für Wirtschaftsgeographie, 44: 167-182. 
Bathelt, H. and Glückler, J. (2002a) Wirtschaftsgeographie. Ökonomische Beziehungen in räumlicher Perspektive (Economic geography. Economic relations in spatial perspective). Stuttgart: UTB - Ulmer.

Bathelt, H. and Glückler, J. (2002b) Wirtschaftsgeographie in relationaler Perspektive: Das Argument der zweiten Transition (Relational economic geography after the second transition). Geographische Zeitschrift, 90. Forthcoming.

Baum, J. A. and Oliver, C. (1992) Institutional embeddedness and the dynamics of organizational populations. American Sociological Review, 57: 540-559.

Berndt, C. (1999) Institutionen, Regulation und Geographie (Institutions, regulation and geography). Erdkunde, 53: 302-316.

Berry, B. J. L. (2002) Book review of 'the spatial economy: cities, regions, and international trade’ by M. Fujita, P. Krugman and A. Venables. Cambridge (MA): MIT Press, 2001 (2nd edition). Annals of the Association of American Geographers, 92: 359-360.

Bhaskar, R. (1975) A Realist Theory of Science. London, New York: Verso (Reprint from 1997).

Bourdieu, P. (1977) Outline of a Theory of Practice. Cambridge: Cambridge University Press.

Bryson, J, Henry, N., Keeble, D. and Martin, R. (eds) (1999) The Economic Geography Reader. Producing and Consuming Global Capitalism. Chichester, New York: Wiley.

Bunge, W. (1973) Ethics and logic in geography. In R. J. Chorley (ed) Directions in Geography. London: Methuen, 317-331.

Chorley, R. J. and Haggett, P. (eds) (1965) Frontiers in Geographical Teaching. London: Methuen.

Chorley, R. J. and Haggett, P. (eds) (1967) Models in Geography. London: Methuen.

Clark, G. L. (1982) Rights, property, and community. Economic Geography, 58: 120-138.

Clark, G. L. (1983) Fluctuations and rigidities in local labor markets. Part 2: reinterpreting relational contracts. Environment and Planning A, 15: 365-377. 
Clark, G. L., Feldman, M. P. and Gertler, M. S. (eds) (2000) The Oxford Handbook of Economic Geography. Oxford: Oxford University Press.

Cliff, A. D., Haggett, P., Ord, J. K. and Versey, G. R. (1981) Spatial Diffusion: A Historical Geography of Epidemics in an Island Community. Cambridge: Cambridge University Press.

Coase, R. H. (1937) The nature of the firm. Economica, 4: 386-405.

Crevoisier, O. (2001): Der Ansatz des kreativen Milieus: Bestandsaufnahme und Forschungsperspektiven am Beispiel urbaner Milieus (The creative milieu: state of the art, research perspectives and the case of urban milieus). Zeitschrift für Wirtschaftsgeographie, 45: 246-256.

Crevoisier, O. and Maillat, D. (1991) Milieu, industrial organization and territorial production system: towards a new theory of spatial development. In R. Camagni (ed) Innovation Networks: Spatial Perspectives. London, New York: Belhaven Press, 13-34.

Curry, L. (1967) Central places in the random space economy. Journal of Regional Science, 7/2 (suppl.): 217-238.

DiMaggio, P. J. (1997) Culture and cognition. Annual Review of Sociology, 23: 263-289.

Dicken, P. (1994) The Roepke lecture in economic geography: global-local tensions: firms and states in the global space-economy. Economic Geography, 70: 101-128.

Dicken, P. (1990) The geography of enterprise. Elements of a research agenda. In M. de Smidt and E. Wever (eds) The Corporate Firm in a Changing World Economy. Case Studies in the Geography of Enterprise. London: Routledge, 234-244.

Dosi, G. (1982) Technological paradigms and technological trajectories: a suggested reinterpretation of the determinants and directions of technical change. Research Policy, 2: $147-162$. 
Dosi, G. (1988) The nature of the innovative process. In G. Dosi, C. Freeman, R. R. Nelson, G. Silverberg and L. L. G. Soete (eds) Technical Change and Economic Theory. London, New York: Pinter, 221-238.

Ettlinger, N. (2001) A relational perspective in economic geography: connecting competitiveness with diversity and difference. Antipode, 33: 216-227.

Fleetwood, S. (2002) Boylan and O'Gorman's causal holism: a critical realist evaluation. Cambridge Journal of Economics, 26, 27-45.

Fujita, M., Krugman, P. and Venables, A. (2001) The Spatial Economy: Cities, Regions, and International Trade. Cambridge (MA): MIT Press (2nd edition).

Gertler, M. S. (1993) Implementing advanced manufacturing technologies in mature industrial regions: towards a social model of technology production. Regional Studies, 27: $665-680$.

Gertler, M. S. (1995) 'Being there': proximity, organization, and culture in the development and adoption of advanced manufacturing technologies. Economic Geography, 71: 1-26.

Giddens, A. (1984) The Constitution of Society. Outline of the Theory of Structuration. Cambridge: Polity Press.

Giddens, A. (1990) The Consequences of Modernity. Stanford (CA): Stanford University Press.

Glückler, J. (1999) Neue Wege geographischen Denkens? Eine Kritik gegenwärtiger Raumkonzepte und ihrer Forschungsprogramme in der Geographie (New ways of geographical reasoning? A critique of contemporary conceptions of space and research designs in geography). Frankfurt/Main: Verlag Neue Wissenschaft.

Glückler, J. (2001) Zur Bedeutung von Embeddedness in der Wirtschaftsgeographie (On the significance of embeddedness in economic geography). Geographische Zeitschrift, 89: 211-226. 
Grabher, G. (1993) Rediscovering the social in the economics of interfirm relations. In G. Grabher (ed) The Embedded Firm. On the Socioeconomics of Industrial Networks. London, New York: Routledge, 1-31.

Granovetter, M. (1985) Economic action and economic structure: the problem of embeddedness. American Journal of Sociology, 91: 481-510.

Granovetter, M. (1992a) Economic institutions as social constructions: a framework for analysis. Acta Sociologica, 35: 3-11.

Granovetter, M. (1992b) Problems of explanation in economic sociology. In N. Nohria and R. G. Eccles (eds) Networks and Organisations: Structure, Form, and Action. Cambridge (MA): Harvard Business School, 25-56.

Haggett, P. (1965) Locational Analysis in Human Geography. London: Arnold.

Hard, G. (1993) Über Räume reden. Zum Gebrauch des Wortes 'Raum’ in sozialwissenschaftlichem Zusammenhang (The use of the term 'space' in sociological context). In J. Mayer (ed) Die aufgeräumte Welt. Raumbilder und Raumkonzepte im Zeitalter globaler Marktwirtschaft. Loccumer Protokolle, 74/92. Loccum: Evangelische Akademie Loccum, 53-78.

Hartshorne, R. (1939) The Nature of Geography. Lancaster, PA: Association of American Geographers.

Harvey, D. (1982) The Limits of Capital. Oxford: Basil Blackwell.

Harvey, D. (1996) Justice, Nature and the Geography of Difference. Oxford: Blackwell. Hettner, A. (1927) Die Geographie. Ihre Geschichte, ihr Wesen und ihre Methoden (Geography. Its history, its character and its methods). Breslau: Hirt.

Hirschman, A. O. (1958) The Strategy of Economic Development. New Haven: Yale University Press.

Hodgson, G. M. (1988) Economics and Institutions: A Manifesto for a Modern Institutional Economics. Cambridge: Polity Press. 
Hume, D. (1758) Eine Untersuchung über den menschlichen Verstand (An investigation into human intellect). Stuttgart: Reclam (German edition from 1982).

Isard, W. (1956) Location and Space-Economy: A General Theory Relating to Industrial Location, Market Areas, Land Use, Trade and Urban Structure. New York, London: Wiley.

Isard, W. (1960) Methods of Regional Analysis: An Introduction to Regional Science. Cambridge (MA), London: MIT Press.

Jessop, B. (1992) Fordism and Post-Fordism: a critical reformulation. In M. Storper and A. J. Scott (eds) Pathways to Industrialization and Regional Development. London, New York: Routledge, 46-69.

Kaldor, N. (1970) The case for regional policies. Scottish Journal of Political Economy, 17: $337-347$.

Krauss, T. (1933) Der Wirtschaftsraum. Gedanken zu seiner geographischen Erforschung (Economic space and its geographical exploration). In T. Krauss (ed) Individuelle Länderkunde und räumliche Ordnung. Erdkundliches Wissen, 7. Wiesbaden: Steiner (edition from 1960), 21-45.

Krugman, P. (1991) Geography and Trade. Leuven: Leuven University Press; Cambridge (MA), London: MIT Press.

Krugman, P. (2000) Where in the world is the 'new economic geography'? In G. L. Clark, M. P. Feldman and M. S. Gertler (eds) The Oxford Handbook of Economic Geography. Oxford: Oxford University Press, 49-60.

Lee, R. (2002) 'Nice maps, shame about the theory'? Thinking geographically about the economic. Progress in Human Geography, 26: 333-355.

Lee, R. and Wills, J. (eds) (1997) Geographies of Economies. London, New York, Sydney: Arnold. 
Lovering, J. (1989) The restructuring debate. In R. Peet and N. Thrift (eds.) New Models in Geography 1. London: Hyman, 198-223.

Lundvall, B.-Å. (1988) Innovation as an interactive process: from producer-user interaction to the national system of innovation. In G. Dosi, C. Freeman, R. R. Nelson, G. Silverberg and L. L. G. Soete (eds) Technical Change and Economic Theory. London, New York: Pinter, 349-369.

Lundvall, B.-Å. (ed) (1992) National Systems of Innovation: Towards a Theory of Innovation and Interactive Learning. London: Pinter.

Lundvall, B.-Å. and Johnson, B. (1994) The learning economy. Journal of Industry Studies, 1: $23-42$.

Lundvall, B.-Å. and Maskell, P. (2000) Nation states and economic development: from national systems of production to national systems of knowledge creation and learning. In G. L. Clark, M. P. Feldman and M. S. Gertler (eds) The Oxford Handbook of Economic Geography. Oxford: Oxford University Press, 353-372.

Lütgens, R. (1921) Grundzüge der Entwicklung des La Plata-Gebietes (Characteristics of the development of the La Plata area). Weltwirtschaftliches Archiv, 17: 359-374.

Martin, R. (1994) Economic theory and human geography. In D. Gregory, R. Martin and G. Smith (eds) Human Geography. Society, Space and Social Science. Houndmills: Macmillan, 21-53.

Martin, R. (1999) The 'new economic geography': challenge or irrelevance? Transactions of the Institute of British Geographers, 24: 387-391.

Martin, R. and Sunley, P. (1996) Paul Krugman's geographical economics and its implications for regional development theory: a critical assessment. Economic Geography, 74: 259-292.

Martin, R. and Sunley, P. (2001) Rethinking the 'economic' in economic geography: broadening our vision or losing our focus? Antipode, 33: 148-161. 
Maskell, P. (2001) The firm in economic geography. Economic Geography, 77: 329-344.

Maskell, P. and Malmberg, A. (1999a) The competitiveness of firms and regions:

'ubiquitification' and the importance of localized learning. European Urban and Regional Studies, 6: 9-25.

Maskell, P. and Malmberg, A. (1999b) Localised learning and industrial competitiveness. Cambridge Journal of Economics, 23: 167-185.

Massey, D. (1985) New directions in space. In D. Gregory and J. Urry (eds) Social Relations and Spatial Structures. Basingstoke: Macmillan, 9-19.

McDowell, L. (2000) Feminists rethink the economic: the economics of gender/the gender of eonomics. In G. L. Clark, M. P. Feldman and M. S. Gertler (eds) The Oxford Handbook of Economic Geography. Oxford: Oxford University Press, 497-517.

Meckelein, W. and Borcherdt, C. (eds) (1970) Tagungsberichte und wissenschaftliche Abhandlungen (Conference proceedings and scientific papers). 37. Deutscher Geographentag Kiel 1969. Wiesbaden: Steiner.

Myrdal, G. (1957) Economic Theory and Underdeveloped Regions. London: Duckworth.

Nelson, R. R. (ed) (1993) National Innovation Systems: A Comparative Analysis. Oxford: Oxford University Press.

Nelson, R. R. (1995) Evolutionary theorizing about economic change. Journal of Economic Literature, 23, 48-90.

Nelson, R. R. and Winter, S. G. (1982) An Evolutionary Theory of Economic Change. Cambridge (MA): Harvard University Press.

Nonaka, I., Toyama, R. and Nagata, A. (2000) A firm as a knowledge-creating entity: a new perspective on the theory of the firm. Industrial and Corporate Change, 9: 1-20.

North, D. C. (1991) Institutions. The Journal of Economic Perspectives, 5: 97-112.

Peck, J. (1996) Workplace: The Social Regulation of Labour Markets. New York: Guilford. 
Perrons, D. (2001) Towards a more holistic framework for economic geography. Antipode, 33: $208-215$.

Philo, C. (1989) Contextuality. In A. Bullock, O. Stallybrass and S. Trombly (eds) The Fontana Dictionary of Modern Thought. London: Fontana Press, 173.

Prahalad, C. and Hamel, G. (1990) The core competence of the corporation. Harvard Business Review, 68: 79-91.

Rodríguez-Pose, A. (2001) Killing economic geography with a 'cultural turn' overdose. Antipode, 33: 176-182.

Romo, F. P. and Schwartz, M. (1995) The structural embeddedness of business decisions: the migration of manufacturing plants in New York State, 1960-1985. American Sociological Review, 60: 874-907.

Saunders, P. (1989) Space, urbanism and the created environment. In D. Held and J. B. Thompson (eds) Social Theory of Modern Societies: Anthony Giddens and His Critics. Cambridge: Cambridge University Press, 215-234.

Saxenian, A. L. (1994) Regional Advantage: Culture and Competition in Silicon Valley and Route 128. Cambridge (MA), London: Harvard University Press.

Sayer, A. (1985) The difference that space makes. In D. Gregory and J. Urry (eds) Social Relations and Spatial Structures. Basingstoke: Macmillan, 49-66.

Sayer, A. (1992) Method in Social Science. London: Routledge.

Sayer, A. (2000) Realism and Social Science. London: Sage.

Sayer, A. and Walker, R. (1992) The New Social Economy: Reworking the Division of Labor. Cambridge (MA), Oxford: Blackwell.

Schamp, E. W. (1983) Grundansätze der zeitgenössischen Wirtschaftsgeographie (Fundamental approaches of contemporary economic geography). Geographische Rundschau, 35: 74-80. 
Schamp, E. W. (2000) Vernetzte Produktion: Industriegeographie aus institutioneller Perspektive (Networked production: industrial geography from institutional perspective). Darmstadt: Wissenschaftliche Buchgesellschaft.

Schätzl, L. (1998) Wirtschaftsgeographie 1: Theorie (Economic geography 1: theory). Paderborn, München, Wien: UTB - Schöningh (7th edition).

Schoenberger, E. (1997) The Cultural Crisis of the Firm. Cambridge (MA), Oxford: Blackwell.

Scott, A. J. (1988) New Industrial Spaces: Flexible Production Organization and Regional Development in North America and Western Europe. London: Pion.

Scott, A. J. (1998) Regions and the World Economy: The Coming Shape of Global Production, Competition, and Political Order. Oxford, New York: Oxford University Press.

Scott, A. J. (2000) Economic geography: the great half-century. Cambridge Journal of Economics, 24: 483-504.

Sheppard, E. (2000) Geography or economics? Conceptions of space, time, interdependence, and agency. In G. L. Clark, M. P. Feldman and M. S. Gertler (eds) The Oxford Handbook of Economic Geography. Oxford: Oxford University Press, 99-119.

Sheppard, E. and Barnes, T. J. (eds) (2000) A Companion to Economic Geography. Oxford, Malden: Blackwell.

Stark, D. (2000) For a sociology of worth. Paper presented at the conference on economic sociology at the edge of the third millenium. Moscow.

Storper, M. (1993) Regional 'worlds' of production: learning and innovation in the technology districts of France, Italy and the USA. Regional Studies, 27: 433-455.

Storper, M. (1995) The resurgence of regional economics, ten years later. European Urban and Regional Studies, 2: 191-221. 
Storper, M. (1997a) The Regional World. Territorial Development in a Global Economy. New York, London: Guilford.

Storper, M. (1997b) Regional economies as relational assets. In R. Lee and J. Wills (eds) Geographies of Economies. London, New York, Sydney: Arnold, 248-258.

Storper, M. (1997c) Territories, flows, and hierarchies in the global economy. In K. R. Cox (ed) Spaces of Globalization. Reasserting the Power of the Local. New York, London: Guilford, 19-44.

Storper, M. and Walker, R. (1989) The Capitalist Imperative. Territory, Technology, and Industrial Growth. New York, Oxford: Basil Blackwell.

Sunley, P. (1996) Context in economic geography: The relevance of pragmatism. Progress in Human Geography, 20: 338-355.

Swedberg, R. and Granovetter, M. (1992) Introduction. In M. Granovetter and R. Swedberg (eds) The Sociology of Economic Life. Oxford: Westview Press, 1-26.

Taylor, M. (1995) The business enterprise, power and patterns of geographical industrialisation. In S. Conti, E. J. Malecki and P. Oinas (eds) The Industrial Enterprise and its Environment: Spatial Perspectives. Avebury: Aldershot, 99-122.

Thrift, N. (1990) For a new regional geography 1. Progress in Human Geography, 14: 272277.

Thrift, N. (2000) Pandora's box? Cultural geographies of economies. In G. L. Clark, M. P. Feldman and M. S. Gertler (eds) The Oxford Handbook of Economic Geography. Oxford: Oxford University Press, 689-704.

Toulmin, S. (1972) Human Understanding, Volume I, General Introduction and Part I: The Collective Use and Evolution of Concepts. Princeton: Princeton University Press. von Böventer, E. (1962) Theorie des räumlichen Gleichgewichts (The theory of spatial equilibrium). Tübingen: Mohr (Siebeck). 
Voppel, G. (1999) Wirtschaftsgeographie: Räumliche Ordnung der Weltwirtschaft unter marktwirtschaftlichen Bedingungen (Economic geography: global spatial order under free market trade). Teubner Studienbücher der Geographie. Stuttgart, Leipzig: Teubner.

Waibel, L. (1933) Das System der Landwirtschaftsgeographie (The system of agricultural geography). In L. Waibel (eds) Wirtschaftsgeographische Abhandlungen - Nummer 1. Leipzig: Hirt, 7-12.

Webber, M. J. and Rigby, D. (1996) The Golden Age Illusion: Rethinking Postwar Capitalism. New York: Guilford.

Werlen, B. (1993) Society, Action and Space. An Alternative Human Geography. London: Routledge.

Werlen, B. (1995) Sozialgeographie alltäglicher Regionalisierungen. Band 1: Zur Ontologie von Gesellschaft und Raum (Social geography of everyday's regionalizations. Vol. 1: an ontology of society and space). Erdkundliches Wissen, 116. Stuttgart: Steiner.

Werlen, B. (2000) Sozialgeographie: Eine Einführung (Social geography: an introduction). Bern, Stuttgart: UTB - Haupt.

Wernerfelt, B. (1984) A resource-based view of the firm. Strategic Management Journal, 5: 171-180.

Williamson, O. E. (1975) Markets and Hierarchies: Analysis and Anti-Trust Implications. New York: Free Press.

Williamson, O. E. (1985) The Economic Institutions of Capitalism. Firms, Markets, Relational Contracting. New York: Free Press.

Zeller, C. (2001) Globalisierungsstrategien - Der Weg von Novartis (Globalization strategies - the path of novartis). Berlin, Heidelberg, New York: Springer.

Zukin, S. and DiMaggio, P. (1990) Introduction. In S. Zukin and P. DiMaggio (eds) Structures of Capital: The Social Organization of the Economy. New York: Cambridge University Press, 1-36. 
Figure 2: Storper's Holy Trinity (Source: Storper 1997a, 42 and 49)

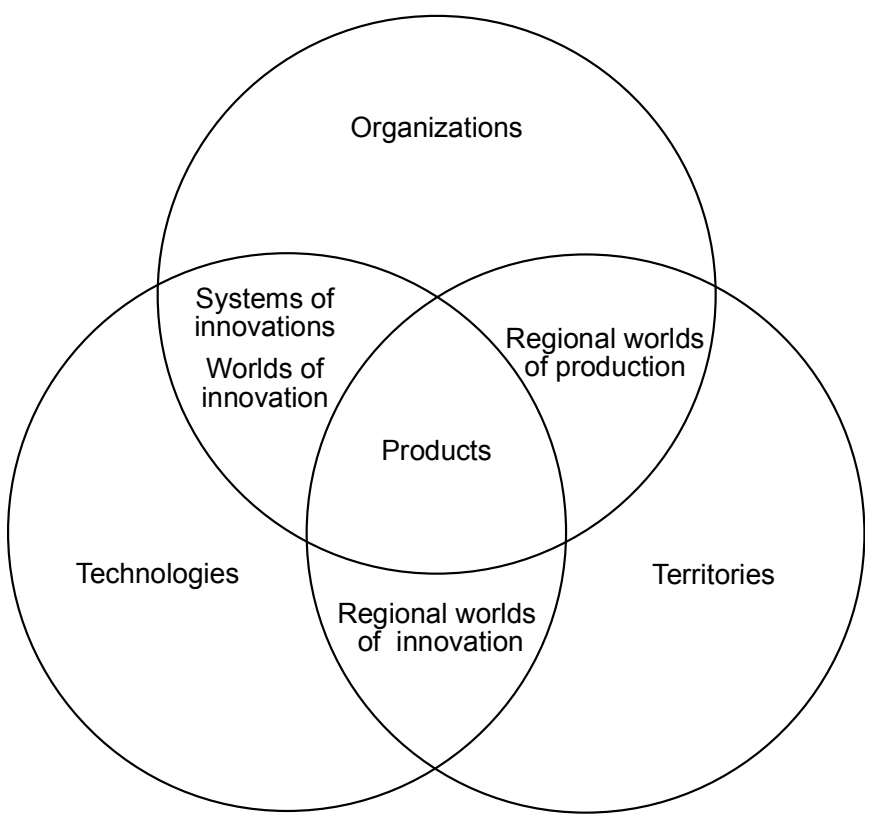


Figure 3: The Four Ions of Economic Geography in a Relational Perspective

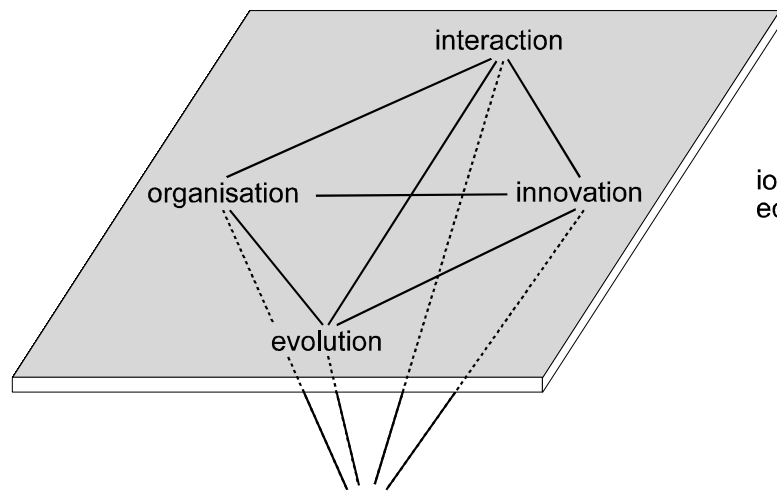

in

economic geography

relational action

in spatial perspective

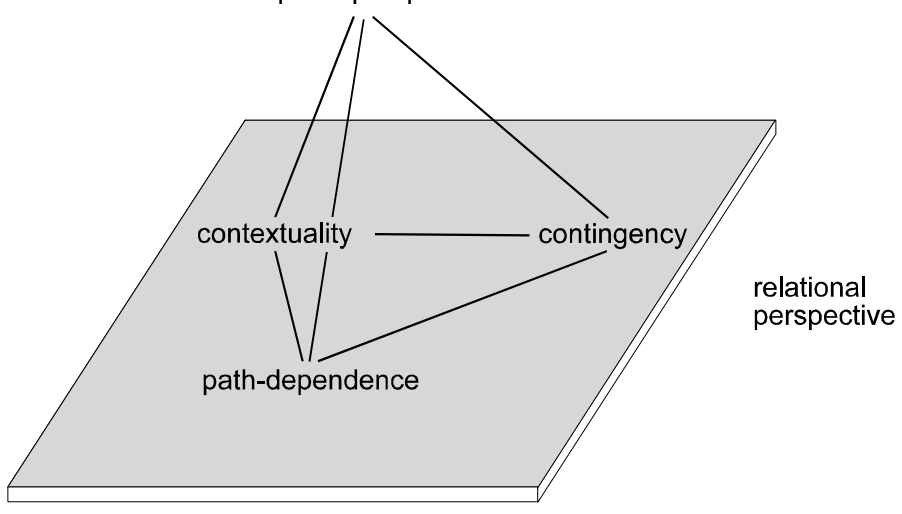


Figure 1: Changing Research Designs in the Paradigms of German Economic Geography

\begin{tabular}{|c|c|c|c|}
\hline $\begin{array}{l}\text { Dimensions of the } \\
\text { research design }\end{array}$ & $\begin{array}{l}\text { Economic geography in } \\
\text { Länderkunde }\end{array}$ & $\begin{array}{l}\text { Regional science (or spatial } \\
\text { analysis) }\end{array}$ & Relational economic geography \\
\hline Conception of space & Space as object and causal factor & Space as object and causal factor & $\begin{array}{l}\text { Space as perspective (geographical } \\
\text { lens) }\end{array}$ \\
\hline Object of knowledge & $\begin{array}{l}\text { Specific economic-space } \\
\text { formations of a landscape }\end{array}$ & $\begin{array}{l}\text { Spatially manifested consequences } \\
\text { of action (structure) }\end{array}$ & $\begin{array}{l}\text { Contextual economic relations } \\
\text { (social practice, process) }\end{array}$ \\
\hline Conception of action & $\begin{array}{l}\text { Environmental determinism/ } \\
\text { possibilism }\end{array}$ & $\begin{array}{l}\text { Atomistic: methodological } \\
\text { individualism }\end{array}$ & $\begin{array}{l}\text { Relational: network theory/ } \\
\text { embeddedness-perspective }\end{array}$ \\
\hline $\begin{array}{l}\text { Epistemological } \\
\text { perspective }\end{array}$ & Realism/naturalism & Neo-positivism/critical rationalism & $\begin{array}{l}\text { Critical realism/evolutionary } \\
\text { perspective }\end{array}$ \\
\hline Research goal & $\begin{array}{l}\text { Ideographic understanding of the } \\
\text { nature of a landscape }\end{array}$ & $\begin{array}{l}\text { Discovery of spatial laws of } \\
\text { economic behavior }\end{array}$ & $\begin{array}{l}\text { De-contextualization of principles } \\
\text { of socio-economic exchange in } \\
\text { spatial perspective }\end{array}$ \\
\hline
\end{tabular}

